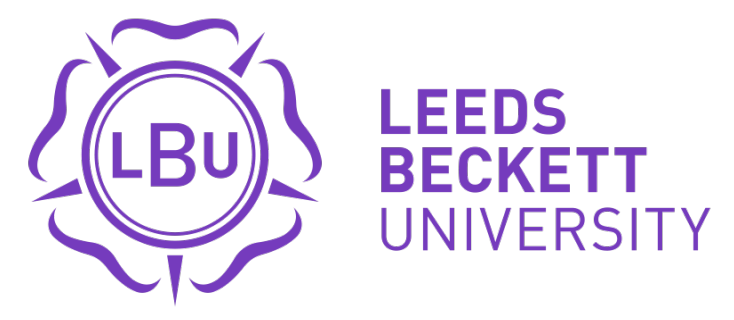

Citation:

Spracklen, K (2014) Leisure studies education: Historical trends and pedagogical futures in the United Kingdom and beyond. Journal of Hospitality, Leisure, Sport and Tourism Education, 15 (1). 20 - 23. ISSN 1473-8376 DOI: https://doi.org/10.1016/j.jhlste.2014.03.002

Link to Leeds Beckett Repository record:

https://eprints.leedsbeckett.ac.uk/id/eprint/168/

Document Version:

Article (Accepted Version)

The aim of the Leeds Beckett Repository is to provide open access to our research, as required by funder policies and permitted by publishers and copyright law.

The Leeds Beckett repository holds a wide range of publications, each of which has been checked for copyright and the relevant embargo period has been applied by the Research Services team.

We operate on a standard take-down policy. If you are the author or publisher of an output and you would like it removed from the repository, please contact us and we will investigate on a case-by-case basis.

Each thesis in the repository has been cleared where necessary by the author for third party copyright. If you would like a thesis to be removed from the repository or believe there is an issue with copyright, please contact us on openaccess@leedsbeckett.ac.uk and we will investigate on a case-by-case basis. 


\section{Leisure Studies Education: Historical Trends and Pedagogical Futures in the United Kingdom and Beyond}

Karl Spracklen, Leeds Metropolitan University, UK

K.Spracklen@leedsmet.ac.uk

\section{Introduction}

My work-place Leeds Metropolitan University (UK) has a global reputation for leisure studies. It was one of the first universities in the United Kingdom to start an undergraduate leisure studies course back in the 1980s, and it has had world-class leisure studies scholarly activity since then. Historically, people like Sheila Scraton, Peter Bramham and Jonathan Long were active in the Leisure Studies Association and the journal Leisure Studies. More recently, Beccy Watson has stepped up to the Managing Editor role at Leisure Studies, while others such have played key roles on the Executive Committee of the Leisure Studies Association. I myself was Chair of the Leisure Studies Association from 2009 until 2013. We still have the Institute for Sport, Physical Activity and Leisure, arguably the strongest research institute in the university, with dozens of people submitted to the United Kingdom HEFCE Research Excellence Framework. I am surrounded in my building with experts in the sociology of sport, gender studies, tourist studies, mobilities, sports development, cultural geographies, cultural tourism, history of sport, sports marketing, sports management, diasporic studies, critical 'race' studies and disability studies. In the building next door there are specialists in sports coaching, physical education, physical activity and health, and various sports sciences. There are even a few of us who define ourselves strictly as leisure studies scholars - for example, my own professorial title is Professor of Leisure Studies.

On the surface, then, Leeds Metropolitan University seems to have retained his strong reputation for leisure studies. But dig a little bit deeper and you will find that things have changed. There might be a research Institute for Sport, Physical Activity and Leisure, but there is no School or Faculty with the word leisure in the title. We have a School of Sport and a School of Events, Tourism and Hospitality. These two Schools sit with the School of Education and Childhood in the Carnegie Faculty. Within the School of Sport there is an academic group that carries the title Leisure, Sport and Entertainment, but academic groups are managerial entities that have little impact on how students and the outside world sees us. Both the School of Sport and the School of Events, Tourism and Hospitality might be argued to be doing leisure studies. But suggesting to senior management that they merge the two 
Schools into a School of Leisure (Studies) will result in a nervous smile and a shake of the head. Each of these Schools has a strong brand that it wants to project to the outside world (we are thrusting and dynamic and open for business), and leisure is seen as something oldfashioned. The School of Sport, as I have said, does still have leisure scholars and leisure taught content (modules, an MA in Leisure, Sport and Culture; PhD students). But as of September 2013, with the removal of BA (Hons) Sport, Leisure and Culture from the School of Sport's portfolio, it no longer has an undergraduate course with leisure in its title.

In this review article, I want to explore the rise and fall of leisure studies in higher education in the United Kingdom. I will contrast what has happened in the United Kingdom with other countries around the world and suggest that there is a clear cycle of subject fields such as sports studies, active recreation, events management and tourism studies breaking away from leisure studies and squeezing leisure studies from the curriculum. This observation about the decline of leisure studies has been made by many others (see Aitchison, 2000; Bramham 2006; Rojek, 2010; Spracklen, 2009), and there is in the work of some these particular scholars a strong pessimism about the future of leisure studies. Given the brief history of the rise and fall of leisure studies here at Leeds Metropolitan University with which I started this article, one might think I aligned myself with the pessimism. But in the final section of this article, I will map out possibilities and opportunities for leisure studies domestically and globally - as a vibrant subject field with a new pedagogical and research focus, and suggest that there are two pedagogical futures for leisure studies in the undergraduate curriculum: challenging students to think critically within otherwise narrowly focussed 'professional' courses; and becoming the new cultural studies.

\section{Historical Trends}

In an interview in the journal Leisure Studies (Andrews, 2006), Alan Tomlinson, Professor of Leisure Studies at the University of Brighton and a key figure in the growth of the subject field in the 1980s, suggested there were three important strands to the evolution of leisure studies. The first strand was associated with sociologists who became interested in the status of leisure in modern society in the 1960s and 1970s. These were people such as Eric Dunning, who was interested in the development of modern sport through the lens of Norbert Elias’ figurationalism; and Ken Roberts (1978) and Stanley Parker (1971), who were interested in the ways leisure and work were defined and delineated. The second strand was associated with academics who came to be interested in leisure after receiving narrowly- 
focussed training in Physical Education. The third strand, according to Tomlinson, came from the policy arena (Andrews, 2006: 259):

The other kind of contributor to leisure studies in the very early days... came from among people who had gone into the more practical area - variants of recreation management or policy. So in the early to mid '70s there were some very important planning and policy and management contributors to the formation of the field of leisure studies: some in the private sector, some in the public sector - that was another extremely important route, but of course they were not establishing what you might call an institutional curriculum-based strength for the academic subject area. Some certainly established areas or pockets of excellence for a while, as did Tony Travis in Urban and Regional Studies at the University of Birmingham. Tony Veal came through there and Judy White came through the unit, which was research-based, with some Masters type courses. Groups in Edinburgh University and North London Polytechnic were also important pioneers in the field.

From the beginning, then, the subject field of leisure studies combined critical social science research about what people did in their non-work lives with more practical content around leisure management and leisure policy. Sports and active recreation ran through both the critical sociological debates about leisure and the practical debates about how to improve people's leisure lives. The foundation of the Leisure Studies Association in 1975 and the creation of the journal Leisure Studies in 1982 established leisure studies as an exciting multidisciplinary subject field, focussed on increasing knowledge about the function of leisure and sport in everyday lives, while helping policy-makers and make leisure central to their planning. In the United Kingdom, local authorities took on the role of providing leisure opportunities for people, building leisure centres and delivering programmes of leisure and sport. Leisure studies attracted support in education and in the 1980s leisure studies undergraduate degree courses started to appear.

These first leisure studies degrees had very similar content. Running through these courses were those three strands Tomlinson mentioned, distilled into taught content: a critical sociology, a policy and management core, and practical elements associated with sports and active recreation that came from Physical Education. Along with these there were some engagements with other social sciences and humanities such as economics and philosophy, and a sport-studies focus at many college that rolled leisure studies and sport science 
together. Similar courses emerged in other parts of the world, in particular North America, Europe, and Australia and New Zealand. These were mainly called leisure studies degrees, though some were badged as sport studies or recreation studies. Crucially, these first leisure studies degrees were often the only form of leisure study possible in each higher education institution that offered them - they were not competing with sports studies, tourism studies, leisure management, sports development and so on.

The success of these undergraduate courses rested partly on their links with policymakers and graduate careers in the leisure industry. But they also owed their success to catching a zeitgeist of fashionable interest in the problem of leisure in post-industrial societies. Students wanted to learn about how leisure could be used to make sense of community and belonging, or how leisure could be used to favour some groups over others. For many students, however, the popularity of leisure studies was associated with their interest in sports, or other forms of physical activity. In the 1980s, leisure studies became legitimate routes for sporty students to enter higher education. They were often the only courses available where students could learn a bit about sport and get to take part in it.

Since the 1980s, sport has become all-pervading in modern society. Watching sport has become an acceptable part of global popular culture, and the radical critique of sport as another opium of the masses has been lost in the chatter about who will win what this year. Playing sport has become once again a moral good rather than a residual element of elite culture. As such, leisure studies courses over the last twenty years have had to face challenges over their content and their existence. The rehabilitation of sport led to claims that the critical sociology of leisure studies was too anti-sport in its content, or too generic to be applicable to sport. In response to this, many course teams teaching leisure studies re-worked their curricula to be more about sport - and many changed the names of their courses to things like leisure and sport studies. Others did away with leisure altogether, becoming sport studies or things like sport and community development. The neo-liberal politics of higher education in this century has also intensified the creation of brand-new sports courses that have taken some leisure studies content away from the old courses, creating degrees in sports studies, sports management or sports development. These new courses fit more easily the interest in sport among the prospective students, sound better to parents concerned with employability, and are easier to market by university managers uncomfortable with the criticality of leisure studies.

So leisure studies found itself a victim of its own success at attracting those interested in sport into higher education; those same people then demanded and got more sporty degrees 
with less problematic critical sociology. At the other end of the leisure subject field, leisure studies was threatened by the emergence of tourism studies and tourism management, followed by events management. Tourism studies has become a mature subject field in its own right, drawing on leisure studies, but also policy studies and geography. Tourism management courses emerged in leisure departments where there were concentrations of scholars aligning themselves with tourism studies. By calling their courses tourism management they followed global trends of reducing the critical social science content of leisure courses and boosting the vocational or professional content. The breakaway of tourism management and tourism studies was driven by academics keen to create a particular nice for their own research, consultancy and teaching - as Aitchison (2001, 2006) suggests, there is an intellectual case to be made for the emergence of tourism studies. The breakaway of events management seems both more pragmatic (chasing a market with no critical intellectual agenda) and ideological (promoting neo-liberalism) at the same time.

This, then, is where leisure studies is right now. There are a few courses in North America that survive, but in the United Kingdom there is no leisure studies at all at undergraduate level - only leisure management. Leisure studies remain within curricula at undergraduate and postgraduate level, and there are a thriving set of sports, events, tourism and hospitality courses that own their origins to leisure studies. But leisure and leisure studies seem to be pariah subjects, ignored by senior managers, parents, prospective students and the wider world. Bramham (2006) predicted that this would happen, and it seems like the old multi-disciplinary leisure studies as described by Tomlinson is dead. Is this the end of leisure studies? I think not.

\section{Pedagogical Futures}

In the introduction to my textbook Leisure, Sports and Society (Spracklen, 2013, p. 3) I define leisure studies as follows:

'Leisure Studies' is the academic discipline that brings a range of social science perspectives to understanding the importance of leisure in modern society. Leisure studies scholars are interested in questions about politics, philosophy, psychology, history, economics and sociology. The discipline allows academics and students to learn what leisure means, how people make choices about their leisure activities, how leisure and sports are funded, how leisure changes, why some leisure activities are regulated, and how leisure is related to fashions and taste. The sociology of leisure is that part of leisure studies which asks questions about the relationship between 
individuals, social groups, society and leisure. It is interested in asking questions about how much of leisure is freely chosen, and how much is a product of social structures and situations

There is no reason to think that this version of leisure studies, more critically sociological and cultural, is not already present in much of the pedagogical content of many courses that fall loosely under the leisure studies banner today. If sports, tourism, events and hospitality course are afraid to mention their origins in leisure studies, they have not completely removed themselves from the leisure studies subject field. Whether they like it or not, they all engage with the idea of leisure and the problem of leisure - and they are all underpinned by the critical sociological lens that remains at the heart of leisure studies. They are all part of leisure studies, even though higher education institutions in the United Kingdom remain reluctant to admit it in their structures and marketing plans. In other countries, this debt to leisure studies is recognised. There are leisure studies schools and departments with active recreation and events management courses. There are still leisure studies courses abroad, through the managementisation of higher education has affected Canada, the United States, Australia and New Zealand. In other countries such as India, Brazil, China and Taiwan, leisure studies is a new subject field fired with enthusiasm, though the critical sociology that underpinned the 'traditional' leisure studies of the 1980s is outweighed in the balance by pedagogies that 'prove' the value of particular kinds of leisure.

So, one pedagogical future of leisure studies is the realisation by different branches of the study of leisure studies that they share many things in common. Sports studies, tourism studies, hospitality management and events management all draw upon ideas about the relationship between policy and theory, society and identity, from leisure studies. Each of these will be improved pedagogically, ethically and politically by taking a strong dose of criticality into their curricula. The purpose of a university, after all, is to make people think about their place in the world, and as the pressures of climate change, globalisation, (post)modernity and global capitalism become more acute, a more morally-based understanding of sports as leisure, or events as leisure, will be useful and necessary.

The other possible pedagogical future is more interesting but probably some way from being achieved. Leisure studies could be re-packaged as a purely critical, socio-cultural subject field, linked to the practice and performance of leisure identities in leisure spaces. Leisure plays an increasingly important role as a space where we resist the mainstream where we find identity and belonging when the working sphere has become purely instrumental. 
There are young people growing up in the United Kingdom and all over the world who are not satisfied with the current systems, and who find meaning and purpose in their leisure lives. For these potential students, leisure is the new culture. In other words, leisure studies could be a new cultural studies, a truly inter-disciplinary subject field that combined history, philosophy, sociology, anthropology, textual studies, media studies and cultural geography to make sense of contemporary leisure lives. This new leisure studies would explicitly reject the neo-liberal paradigm of employability and align itself with a radical politics of resistance. This leisure studies would be a leisure studies that could be acceptable to mainstream sociology and cultural studies departments, and hence ultimately acceptable to academics and learned societies aligned with those disciplines. The new leisure studies would be able to refresh sociology and cultural studies and draw critical young thinkers from the sixth form into higher education.

\section{References}

Aitchison, C. (2000). Poststructural feminist theories of representing others: a response to the 'crisis' in leisure studies' discourse. Leisure Studies, 19(3), 127-144.

Aitchison, C. (2001). Theorizing Other discourses of tourism, gender and culture: Can the subaltern speak (in tourism)?. Tourist studies, 1(2), 133-147.

Aitchison, C. (2006). The critical and the cultural: explaining the divergent paths of leisure studies and tourism studies. Leisure Studies, 25(4), 417-422.

Andrews, D. (2006). Leisure studies: Progress, phases and possibilities -an interview with Alan Tomlinson. Leisure Studies, 25(3), 257-273.

Bramham, P. (2006). Hard and disappearing work: Making sense of the leisure project. Leisure Studies, 25(4), 379-390.

Parker, S. (1976). The sociology of leisure. London: Allen and Unwin.

Roberts, K. (1978). Contemporary society and the growth of leisure. London: Longman. 
Rojek, C. (2010). The labour of leisure. London: Sage.

Spracklen, K. (2009). The meaning and purpose of leisure: Habermas and leisure at the end of modernity. Basingstoke: Palgrave Macmillan. 